\title{
SERIAL MEASUREMENTS OF THE PULMONARY DIFFUSING CAPACITY FOR CARBON MONOXIDE IN A GROUP OF MEN EMPLOYED IN INDUSTRY
}

\author{
BY \\ J. J. DALY AND J. W. ROE \\ From the Departments of Medicine and Preventive Medicine, University of Sheffield
}

Increasing attention has been given to the use of serial measurements of lung function in clinical and epidemiological studies of respiratory disease (Shephard, Turner, Carey, and Phair, 1960 ; Ashford, Forwell, and Routledge, 1960 ; Bates, Knott, and Christie, 1956). For such studies it is important to know the reproducibility of the measurements used, and interest in this respect has concentrated on ventilatory function. Though numerous studies have been concerned with defining the factors which influence the pulmonary diffusing capacity $\left(\mathrm{D}_{\mathrm{Lco}}\right)$ (Forster, 1957 ; Turino, Brandfonbrener, and Fishman, 1959; Ross, Frayser, and Hickam, 1959 ; Cadigan, Marks, Ellicott, Jones, and Gaensler, 1961), few have attempted to assess its variability over an interval of time in the normal individual. The purpose of the present study was to make serial measurements of $\mathbf{D}_{\text {Lco }}$ in a group of men working in industry. An attempt was also made to determine whether changes in lung function occurred as a result of exposure to atmospheric conditions existing in the iron-foundry section of the work. The principal contaminants were the pyrolysis products of "core-bond" which is used in casting.

\section{METHODS}

Twelve healthy men aged between 33 and 60 years (average 45 years) were studied. Their average height was 67 inches, their average weight $163 \mathrm{lb}$, and their average body surface area $1.85 \mathrm{sq}$. $\mathrm{m}$. None had respiratory symptoms. Six of the subjects worked in an iron foundry and the remainder were employed in clerical and other capacities in another department of the same works.

Pulmonary function studies were done on three occasions over a period of three to five weeks; the first two studies were made at the end of a subject's normal working day, and the interval between these was one to two weeks. The final set of measurements in each individual was made at the end of his two weeks' annual holiday but before his return to work.
Functional residual capacity and residual volume were obtained by a closed circuit helium method on each occasion (Gilson and Hugh-Jones, 1949). The forced expiratory volume in $0.75 \mathrm{sec}$. (F.E.V.0.75) was measured using a modified form of the apparatus described by Gaensler (Gaensler, 1951), and peak expiratory flow (P.E.F.) was determined with a flow meter (Wright and McKerrow, 1959). Five measurements of F.E.V.0.75 and P.E.F. were made on each visit, and the mean of the three best efforts was used. The $\mathrm{D}_{\text {Lco }}$ was determined by a single-breath technique previously described (Ogilvie, Forster, Blakemore, and Morton, 1957). A minimum of two estimates was obtained at each visit. In calculating the $D_{\text {Lco }}$ a correction was made for the equilibrium pressure of $\mathrm{CO}$ in the blood, which was determined by a rebreathing method (Sjöstrand, 1948).

\section{RESUlTS}

The table shows the results of measurements of ventilatory function and $D_{\text {Lco }}$ with the dates on which they were obtained. The results of the ventilatory measurements and $D_{\text {Lco }}$ were within the "predicted" range in all subjects and the ratio of residual lung volume to total lung capacity ranged from $20 \%$ to $43 \%$. The changes in measurements between visits were small and did not correlate with the known changes in the environment.

Ventilatory MEasurements.-The average coefficient of variation* of F.E.V $\cdot_{0.75}$ between visits was $6.3 \%$, with a range of $2.2 \%$ to $14.2 \%$, and that of P.E.F. was $6.4 \%$, with a range of $0.8 \%$ to $12.8 \%$.

Pulmonary Diffusing Capacity.-The average coefficient of variation of $D_{L c o}$ between visits was $4.2 \%$, with a range of $0.5 \%$ to $6.4 \%$, and that of a single measurement was $6.1 \%$, with a range of $3.8 \%$ to $9.5 \%$. The average coefficient of variation between measurements on the same day was $4.3 \%$, with a range of $0.9 \%$ to $5.6 \%$.

\footnotetext{
*Here and elsewhere in this paper the term " average coefficient of variation" should be understood as the root mean square of
} the coefficients for the 12 subjects. 
TABLE

F.E.V.0.75 AND P.E.F. MEASURED ON THREE SEPARATE OCCASIONS IN 12 SUBJECTS

\begin{tabular}{|c|c|c|c|c|c|c|c|c|c|}
\hline \multirow{2}{*}{$\begin{array}{c}\text { Subject } \\
\text { H.C. }\end{array}$} & \multirow{2}{*}{$\begin{array}{c}\text { Date } \\
4 / 7 \\
13 / 7 \\
4 / 8\end{array}$} & \multicolumn{3}{|c|}{$\underset{\text { (ml./min./mm. }}{\text { DLeo }}$} & \multirow{2}{*}{$\begin{array}{c}\begin{array}{c}\text { Average } \\
\text { Dleo }\end{array} \\
18 \cdot 4 \\
18.4 \\
18.6\end{array}$} & \multirow{2}{*}{$\begin{array}{c}\begin{array}{c}\text { Modified } \\
\text { DLco } \\
\text { (Average) }\end{array} \\
18 \cdot 3 \\
18 \cdot 0 \\
18 \cdot 2\end{array}$} & \multirow{2}{*}{$\begin{array}{c}\begin{array}{r}\text { R.V. } \\
\text { (1. B.T.P.S.) }\end{array} \\
\begin{array}{c}1.886 \\
1.914 \\
1.749\end{array}\end{array}$} & \multirow{2}{*}{$\begin{array}{c}\begin{array}{c}\text { F.E.V.0.75 } \\
(1 .)\end{array} \\
1 \cdot 60 \\
2 \cdot 13 \\
2 \cdot 25\end{array}$} & \multirow{2}{*}{$\begin{array}{c}\text { P.E.F. } \\
\text { (1./min.) } \\
3.95 \\
4.67 \\
4.63\end{array}$} \\
\hline & & $\begin{array}{l}17 \cdot 5 \\
19 \cdot 3 \\
19 \cdot 8\end{array}$ & $\begin{array}{l}19 \cdot 9 \\
17 \cdot 4 \\
18 \cdot 1\end{array}$ & $\begin{array}{r}17 \cdot 8 \\
17 \cdot 9\end{array}$ & & & & & \\
\hline C.P. & $\begin{array}{r}4 / 7 \\
13 / 7 \\
28 / 7\end{array}$ & $\begin{array}{l}35 \cdot 8 \\
35 \cdot 2 \\
32 \cdot 7\end{array}$ & $\begin{array}{l}36 \cdot 9 \\
35 \cdot 5 \\
37 \cdot 3\end{array}$ & $\begin{array}{l}36 \cdot 7 \\
33 \cdot 9\end{array}$ & $\begin{array}{l}36 \cdot 5 \\
35 \cdot 4 \\
34 \cdot 6\end{array}$ & $\begin{array}{l}36 \cdot 0 \\
35 \cdot 0 \\
34 \cdot 2\end{array}$ & $\begin{array}{l}1.495 \\
1.452 \\
1.403\end{array}$ & $\begin{array}{l}3 \cdot 20 \\
3 \cdot 33 \\
3 \cdot 25\end{array}$ & $\begin{array}{l}5 \cdot 33 \\
5 \cdot 62 \\
5 \cdot 55\end{array}$ \\
\hline R.H. & $\begin{array}{r}11 / 7 \\
18 / 7 \\
8 / 8\end{array}$ & $\begin{array}{l}22 \cdot 3 \\
21 \cdot 9 \\
21 \cdot 0\end{array}$ & $\begin{array}{l}19 \cdot 4 \\
22 \cdot 3 \\
21 \cdot 2\end{array}$ & & $\begin{array}{l}20 \cdot 9 \\
22 \cdot 1 \\
21 \cdot 1\end{array}$ & $\begin{array}{l}20 \cdot 5 \\
21 \cdot 4 \\
20 \cdot 7\end{array}$ & $\begin{array}{l}1 \cdot 818 \\
2 \cdot 004 \\
1.530\end{array}$ & $\begin{array}{l}2 \cdot 37 \\
2 \cdot 25 \\
2 \cdot 33\end{array}$ & $\begin{array}{l}5 \cdot 18 \\
5 \cdot 28 \\
5 \cdot 25\end{array}$ \\
\hline L.H. & $\begin{array}{r}12 / 7 \\
20 / 7 \\
8 / 8\end{array}$ & $\begin{array}{l}34 \cdot 1 \\
30 \cdot 7 \\
32 \cdot 5\end{array}$ & $\begin{array}{l}30 \cdot 9 \\
29 \cdot 7 \\
29 \cdot 8\end{array}$ & & $\begin{array}{l}32 \cdot 5 \\
30 \cdot 2 \\
31 \cdot 2\end{array}$ & $\begin{array}{l}31 \cdot 7 \\
29 \cdot 5 \\
29 \cdot 1\end{array}$ & $\begin{array}{l}1 \cdot 318 \\
1 \cdot 347 \\
1 \cdot 526\end{array}$ & $\begin{array}{l}2 \cdot 07 \\
2 \cdot 30 \\
2 \cdot 38\end{array}$ & $\begin{array}{l}5 \cdot 03 \\
4 \cdot 90 \\
4 \cdot 93\end{array}$ \\
\hline B.G. & $\begin{array}{r}11 / 7 \\
18 / 7 \\
3 / 8\end{array}$ & $\begin{array}{l}31 \cdot 3 \\
30 \cdot 0 \\
29 \cdot 4\end{array}$ & $\begin{array}{l}29 \cdot 7 \\
31 \cdot 3 \\
27 \cdot 6\end{array}$ & $26 \cdot 9$ & $\begin{array}{l}30 \cdot 5 \\
30 \cdot 7 \\
28 \cdot 0\end{array}$ & $\begin{array}{l}30 \cdot 2 \\
30 \cdot 1 \\
27 \cdot 3\end{array}$ & $\begin{array}{l}2 \cdot 149 \\
2 \cdot 152 \\
2 \cdot 245\end{array}$ & $\begin{array}{l}2 \cdot 98 \\
2 \cdot 67 \\
2 \cdot 85\end{array}$ & $\begin{array}{l}4 \cdot 73 \\
4 \cdot 33 \\
5 \cdot 83\end{array}$ \\
\hline G.K. & $\begin{array}{r}7 / 7 \\
12 / 7 \\
7 / 8\end{array}$ & $\begin{array}{l}22 \cdot 4 \\
22 \cdot 0 \\
24 \cdot 1\end{array}$ & $\begin{array}{l}22 \cdot 1 \\
20 \cdot 6 \\
23 \cdot 8\end{array}$ & $\begin{array}{l}24 \cdot 6 \\
25 \cdot 3\end{array}$ & $\begin{array}{l}23 \cdot 0 \\
21 \cdot 3 \\
24 \cdot 4\end{array}$ & $\begin{array}{l}23 \cdot 2 \\
21 \cdot 0 \\
23 \cdot 7\end{array}$ & $\begin{array}{l}2 \cdot 213 \\
1 \cdot 947 \\
2 \cdot 432\end{array}$ & $\begin{array}{l}1.70 \\
1.50 \\
1.47\end{array}$ & $\begin{array}{l}2 \cdot 67 \\
2 \cdot 20 \\
2 \cdot 83\end{array}$ \\
\hline E.J. & $\begin{array}{r}3 / 7 \\
19 / 7 \\
8 / 8\end{array}$ & $\begin{array}{l}29 \cdot 8 \\
28 \cdot 8 \\
28 \cdot 0\end{array}$ & $\begin{array}{l}28 \cdot 7 \\
31 \cdot 7 \\
29 \cdot 1\end{array}$ & $28 \cdot 7$ & $\begin{array}{l}29 \cdot 1 \\
30 \cdot 3 \\
28 \cdot 6\end{array}$ & $\begin{array}{l}28 \cdot 6 \\
30 \cdot 1 \\
28 \cdot 2\end{array}$ & $\begin{array}{l}1 \cdot 682 \\
2 \cdot 402 \\
2 \cdot 248\end{array}$ & $\begin{array}{l}2 \cdot 40 \\
2 \cdot 18 \\
2 \cdot 15\end{array}$ & $\begin{array}{l}4 \cdot 78 \\
4 \cdot 78 \\
4 \cdot 87\end{array}$ \\
\hline E.B. & $\begin{array}{r}5 / 7 \\
10 / 7 \\
8 / 8\end{array}$ & $\begin{array}{l}23 \cdot 3 \\
23 \cdot 9 \\
24 \cdot 2\end{array}$ & $\begin{array}{l}17 \cdot 8 \\
23 \cdot 0 \\
23 \cdot 1\end{array}$ & $20 \cdot 7$ & $\begin{array}{l}20 \cdot 6 \\
23 \cdot 5 \\
23 \cdot 7\end{array}$ & $\begin{array}{l}20 \cdot 7 \\
23 \cdot 4\end{array}$ & $\frac{2 \cdot 160}{2 \cdot \overline{424}}$ & $\begin{array}{l}1.95 \\
1.60 \\
1.77\end{array}$ & $\begin{array}{l}4 \cdot 78 \\
4 \cdot 87 \\
4 \cdot 75\end{array}$ \\
\hline C.W. & $\begin{array}{r}6 / 7 \\
14 / 7 \\
4: 8\end{array}$ & $\begin{array}{l}23 \cdot 6 \\
22 \cdot 3 \\
20 \cdot 4\end{array}$ & $\begin{array}{l}22 \cdot 3 \\
22 \cdot 1 \\
21 \cdot 9\end{array}$ & $\begin{array}{l}22 \cdot 7 \\
21 \cdot 1\end{array}$ & $\begin{array}{l}22 \cdot 9 \\
22 \cdot 2 \\
21 \cdot 1\end{array}$ & $\begin{array}{l}22 \cdot 6 \\
21 \cdot 7 \\
20 \cdot 7\end{array}$ & $\begin{array}{l}1.977 \\
1.659 \\
1.479\end{array}$ & $\begin{array}{l}1.53 \\
1.60 \\
1.47\end{array}$ & $\begin{array}{l}2 \cdot 83 \\
2 \cdot 70 \\
3.05\end{array}$ \\
\hline A.B. & $\begin{array}{r}5 / 7 \\
10 / 7 \\
30 / 7\end{array}$ & $\begin{array}{l}24 \cdot 0 \\
22 \cdot 6 \\
20 \cdot 9\end{array}$ & $\begin{array}{l}22 \cdot 4 \\
21 \cdot 3 \\
21 \cdot 8\end{array}$ & $\begin{array}{l}25 \cdot 7 \\
19 \cdot 9 \\
20 \cdot 4\end{array}$ & $\begin{array}{l}24 \cdot 0 \\
21 \cdot 3 \\
21 \cdot 0\end{array}$ & $\begin{array}{l}23.4 \\
20.9 \\
20.5\end{array}$ & $\frac{1 \cdot 801}{1 \cdot \overline{796}}$ & $\begin{array}{l}2 \cdot 27 \\
2 \cdot 05 \\
2 \cdot 12\end{array}$ & $\begin{array}{l}4.80 \\
5.00 \\
5.03\end{array}$ \\
\hline J.J. & $\begin{array}{r}3 / 7 \\
19 / 7 \\
3 / 8\end{array}$ & $\begin{array}{l}26 \cdot 4 \\
24 \cdot 3 \\
23 \cdot 5\end{array}$ & $\begin{array}{l}23 \cdot 6 \\
24 \cdot 3 \\
21 \cdot 3\end{array}$ & $20 \cdot 8$ & $\begin{array}{l}25 \cdot 0 \\
24 \cdot 3 \\
21 \cdot 9\end{array}$ & $\begin{array}{l}24 \cdot 9 \\
24 \cdot 6 \\
21 \cdot 6\end{array}$ & $\begin{array}{l}2 \cdot 322 \\
2 \cdot 303 \\
2 \cdot 288\end{array}$ & $\begin{array}{l}3.00 \\
2.85 \\
2.88\end{array}$ & $\begin{array}{l}5 \cdot 30 \\
5 \cdot 65 \\
5 \cdot 83\end{array}$ \\
\hline E.T. & $\begin{array}{r}6 / 7 \\
14 / 7 \\
4 / 8\end{array}$ & $\begin{array}{l}32.4 \\
31.8 \\
29.9\end{array}$ & $\begin{array}{l}33 \cdot 5 \\
31 \cdot 7 \\
30 \cdot 3\end{array}$ & & $\begin{array}{l}33 \cdot 0 \\
31 \cdot 8 \\
30 \cdot 1\end{array}$ & $\begin{array}{l}32 \cdot 4 \\
31 \cdot 2 \\
29 \cdot 4\end{array}$ & $\begin{array}{l}2 \cdot 615 \\
2 \cdot 549 \\
2 \cdot 509\end{array}$ & $\begin{array}{l}2 \cdot 70 \\
2 \cdot 50 \\
2 \cdot 85\end{array}$ & $\begin{array}{l}4 \cdot 03 \\
5 \cdot 00 \\
4 \cdot 85\end{array}$ \\
\hline
\end{tabular}

\section{Discussion}

Ogilvie, Forster, Blakemore, and Morton (1957) reported that the coefficients of variation of singlebreath $\mathrm{D}_{\mathrm{L}_{\mathrm{co}}}$ on a single day and over an interval in a group of normal subjects were $5.8 \%$ and $8.5 \%$ respectively. These coefficients are greater than the corresponding values for the present study, but the latter were obtained over a shorter interval of time. Cadigan et al. (1961) reported a coefficient of variation of $D_{\text {Lco }}$ of $8.9 \%$ in 12 normal subjects and noted a close correlation between $D_{L c o}$ and the alveolar volume at which the measurement was made. They concluded that most of the variation in $D_{\text {Lco }}$ was attributable to the variation in alveolar volume, and, by controlling the latter, the coefficient of variation of $D_{\text {Lco }}$ was reduced to $3.2 \%$. In the present study no attempt was made to control alveolar volume, and there was no consistent relationship between it and $D_{\text {Lco }}$. In only four subjects was there a strong association between alveolar volume and $\mathbf{D}_{\mathrm{LC} \text { ) }}$ as illustrated in Figure 1. In the remaining eight subjects variations in $\mathbf{D}_{\text {Lco }}$ were unrelated to alveolar volume, as illustrated in Figure 2. These observations do not conflict with the view that $D_{L i o}$ is dependent on lung volume because the changes in alveolar volume in the present study were generally small, being determined by the degree of the individual's effort. The results indicate that in this study alveolar volume was not the only determinant of variations in $\mathbf{D}_{\text {Lco }}$.

It has been pointed out previously that $D_{\text {Lco }}$ decreases with an increase in breath-holding time (Ogilvie et al., 1957). Variation in breath-holding time was not an important factor in the present investigation becatuse the range in any individual did not exceed 3 seconds. Jones and Meade have provided evidence that the differences in inspiratory time and the time taken for expiration of the alveolar sample are factors influencing the reproducibility of the measurement (Jones and Meade, 1961). They calculated a "modified breath-holding time" and the reproducibility of measurements of $\mathbf{D}_{\mathbf{L} \text { co }}$ in a normal individual was improved by the use of this modification. The $D_{\text {Lco }}$ was recalculated from the results obtained in the 


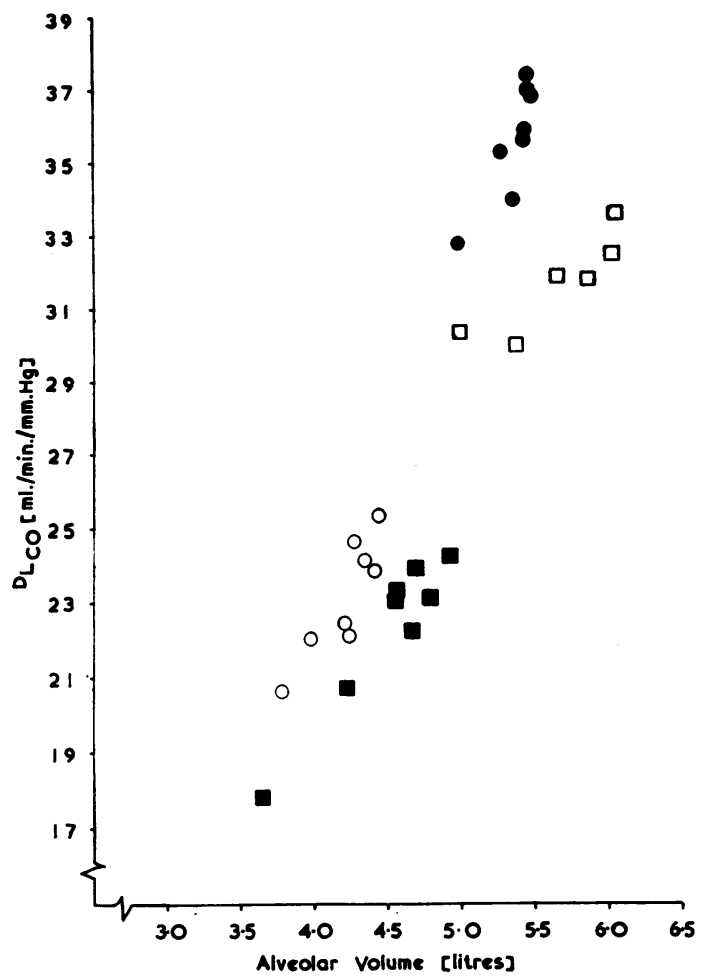

FIG. 1. Diffusing capacity plotted against alveolar volume for four subjects in whom these variables were strongly associated. The values for each subject are represented by symbols of a different shape.

present study using the modified breath-holding time, and the values may be compared with those obtained by the conventional method (see table). In most subjects the modified values are lower but the overall scatter was not reduced. No measurements were made using early alveolar samples, as described by Jones and Meade (1961).

A disadvantage of the single-breath technique for measuring $D_{L c o}$ is that the residual volume is separately determined. Changes in the residual volume greater than $100 \mathrm{ml}$. did occur in eight subjects. The average coefficient of variation for the 12 subjects was $7.4 \%$, which is in agreement with the reports of other workers (Rahn, Fenn, and Otis, 1949 ; Comroe, Forster, DuBois, Briscoe, and Carlsen, 1955).

Previous investigators have reported an influence of atmospheric changes on $\mathrm{CO}$ uptake in subjects with chronic respiratory disease (Shephard et al., 1960). The present study offered an

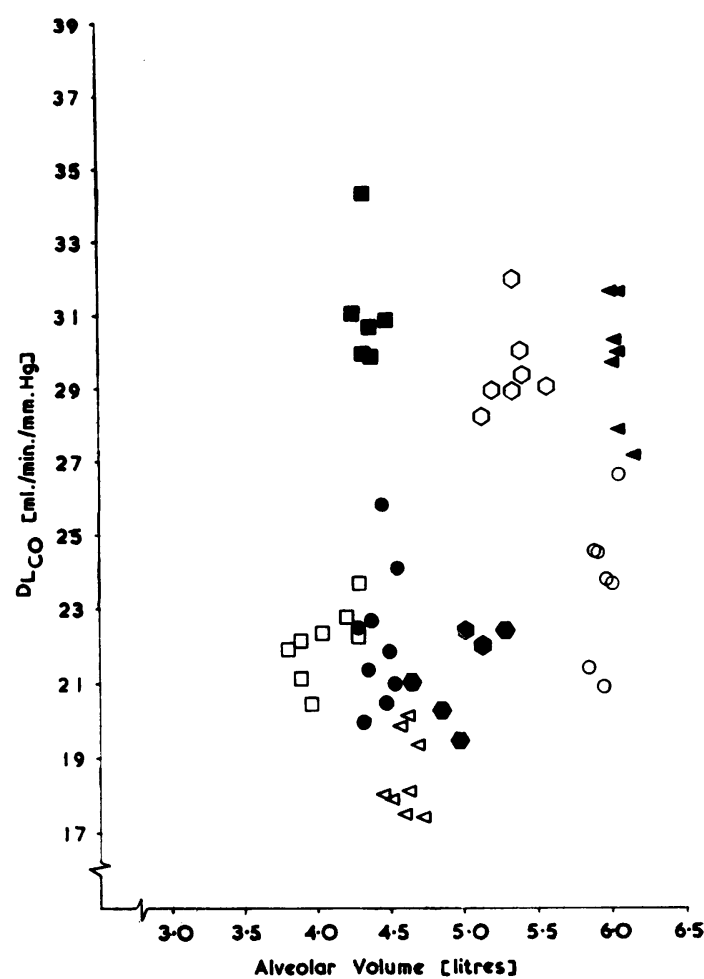

FIG. 2. Diffusing capacity plotted against alveolar volume for eight subjects in whom these measurements were not associated. The values for each subject are represented by symbols of a different shape.

opportunity of assessing the effect of a contaminated industrial environment on lung function inasmuch as half the subjects worked in a foundry and all were studied before and after their annual two weeks' holiday. There was no evidence that the changes in environment influenced the measurements as judged by a comparison of the results in the two groups of subjects. This does not exclude the possibility that changes in $D_{L c o}$ or ventilatory function may occur either during acute exposure to conditions existing in the foundry or over a longer period of time than was used in the present study.

\section{SUMMARY}

Estimates of ventilatory function and singlebreath $\mathbf{D}_{\text {Lco }}$ were made on three separate occasions at intervals of one to three weeks on 12 normal men, of whom six were employed in an iron foundry. 
The average coefficient of variation of F.E.V. ${ }_{0.75}$ between visits was $6.3 \%$, that of P.E.F. $6.4 \%$, and that of $D_{\text {Lco }} 4.2 \%$. The reproducibility of $D_{L c o}$ was not improved by the use of a modified breath-holding time.

There was no consistent difference between the changes in lung function occurring in the six foundry workers and those occurring in the other men.

We wish to thank Dr. H. N. Skelton and Mr. B. W. Roome for their co-operation. Mr. J. Bamforth gave valuable technical assistance. We are grateful to the 12 men who volunteered to take part in the study.

This investigation, which was carried out on behalf of the Joint U.S.-U.K. Board on Cardio-respiratory Disease of the United States Public Health Service, was supported by a grant (H-4775) from the National Heart Institute, United States Public Health Service.

\section{REFERENCES}

Ashford, J. R., Forwell, G. D., and Routledge, R. (1960). Brit. J. industr. Med., 17, 114.

Bates, D. V., Knott, J. M. S., and Christie, R. V. (1956). Ouart. J. Med., $25,137$.

Cadigan, J. B., Marks, A., Ellicott, M. F., Jones, R. H., and Gaensler, E. A. (1961). J. clin. Invest., 40, 1495.

Comroe, J. H., Jr., Forster, R. E., DuBois, A. B., Briscoe, W. A. and Carlsen, E. (1955). The Lung. Clinical Physiology and Pulmonary Function Tests. Year Book Publishers, Chicago.

Forster, R. E. (1957). Physiol. Rev., 37, 391.

Gaensler, E. A. (1951). Amer. Rev. Tuberc., 64, 256.

Gilson, J. C., and Hugh-Jones, P. (1949). Clin. Sci., 7, 185.

Jones, R. S., and Meade, F. (1961). Quart. J. exp. Physiol., 46, 131.

Ogilvie, C. M., Forster, R. E., Blakemore, W. S., and Morton, J. W. (1957). J. clin. Invest., 36, 1.

Rann, H., Fenn, W. O., and Otis, A. B. (1949). J. appl. Physiol., 1, 725.

Ross, J. C., Frayser, R., and Hickam, J. B. (1959). J. clin. Invest., 38, 916 .

Shephard, R. J., Turner, M. E., Carey, G. C. R., and Phair, J. J. (1960). J. appl. Physiol., 15, 70.

Siöstrand, T. (1948). Acta physiol. scand., 1e, 201.

Turino, G. M., Brandfonbrener, M., and Fishman, A. P. (1959). J. clin. Invest., 38, 1186.

Wright, B. M., and McKerrow, C. B. (1959). Brit. med. J., 2, 1041. 